\title{
Effect of organoclay reinforcement on the mechanical and thermal properties of unsaturated polyester resin composites
}

IbarRa Miguel D. ABOBO - Chemistry Department, College of Science, De La Salle University, Manila, Philippines

LoIDA D. RODRIGUEZ - Chemrez Product Solutions Inc., Quezon City, Philippines

SoNIA D. SALVADOR - D\&L Industries Inc., Quezon City, Philippines

Henry C. SIY - Chemrez Product Solutions Inc., Quezon City, Philippines

David P. PENALOZA JR. - Chemistry Department, College of Science,

De La Salle University, Manila, Philippines

Érkezett: 2020. 10. 18. - Received: 18. 10. 2021. " https://doi.org/10.14382/epitoanyag-jsbcm.2021.10

\section{ABSTRACT}

Unsaturated polyester resin (UPR) is a popular material of choice for composite materials, particular in glass fiber-reinforced plastics (FRP) and casting resins (non-reinforced). Our study presents the preparation of clay-based UPR composite materials employing various loadings of organo-modified montmorillonite clay as a filler to a UPR serving as the matrix material that resulted in enhanced thermal and mechanical properties compared to a bare UPR. Wetting behavior of the resulting composites was much better than UPR only. Such property enhancements were connected to the exfoliated morphology of the composite materials. Tensile measurements through universal testing machine was carried out to measure tensile strength while thermal stability was characterized using thermogravimetric analysis. Wetting behavior of the composite materials was evaluated using contact angle measurements. Evaluation of the structure and morphology of the composite materials as well as clay fillers was determined through scanning electron microscopy (SEM), Fourier transform (FTIR) infrared spectroscopy and x-ray diffraction (XRD) technique.

Keywords: unsaturated polyester resin, nanocomposite, organo-modified clay, montmorillonite, modification

Kulcsszavak: telítetlen poliészter gyanta, nanokompozit, szervesen módosított agyag, montmorillonit, módosítás

\section{Introduction}

Unsaturated polyester resin (UPR) is a condensation product between the reaction of unsaturated acids or anhydrides and diols. UPR is usually dissolved in styrene which also serves as the crosslinking agent [1]. Addition of a small amount of an initiator, such as methyl ethyl ketone peroxide (MEKP), initiates the polymerization of styrene bridges bound to the unsaturated points of the polyester producing a highly crosslinked system. The presence of an unsaturated double bond provides the site for crosslinking making UPRs thermosetting polymers of major importance. UPRs are currently the most commonly used matrix for fiber-reinforced plastics. Among their applications are in construction, marine and land transportation industries, coatings, etc. To maximize the use of UPRs, modification methods of these resins are geared towards toughening and reinforcement, flame proofing and improving heat resistance [2-6].

One viable modification for UPRs is by clay reinforcement resulting in the preparation of clay-based polymer nanocomposites. Clay-based polymer nanocomposites are a class of inorganic-organic hybrids having a polymer matrix reinforced with a small loading $(<10 \%)$ of nanometric-sized clay platelets. The term nanocomposite refers to a combination
Ibarra Miguel D. ABOBO MS Chemistry graduate of De La Salle University, Manila, Philippines

Loida D. RODRIGUEZ

Design and Development (D\&D) manager, Chemrez Product Solutions Inc., Quezon City, Philippines

Sonia D. SALVADOR Consultant, D\&L Industries, Inc., Quezon City, Philippines

Henry C. SIY General Manager, Chemrez Product Solutions Inc., Quezon City, Philippines

David P. PENALOZA Jr. Associate professor in the Chemistry Department, College of Science, De La Salle University, Manila, Philippines. His research interests focus on self-assembled systems and nanostructured materials of two or more materials where one of the phases has one, two or three dimensions within the nanometer $\left(10^{-9} \mathrm{~m}\right)$ range [7-11]. Due to the small size and the high surface-tovolume ratio of the inorganic filler at this length scale, the polymer nanocomposites have exhibited remarkable property enhancements and new properties compared to their unfilled polymer and conventional composites. The reinforcing material having at least one dimension in the nanometer length scale can be made up of particles, sheets or fibers. In the case of a clay-based polymer nanocomposite, the inorganic phase is a layered silicate clay. It has a layered structure consisting of stacks of silica platelets each having a thickness of about one nanometer [12-14].

One major drawback of preparing polymer/clay nanocomposites is the incompatibility of the inorganic clay with the organic polymer. This can be remedied by surface modification of the montmorillonite clay using organic intercalating agents to make it more compatible with the polymer matrix [15-18]. This will in turn allow for good dispersion and enhanced properties. Typical loading of clays is at $<10 \%$ for optimum response.

The main objective of this study is to prepare an unsaturated polyester resin (UPR)/clay nanocomposite and 
to enhance the tensile strength with respect to the neat resin. Various characterization techniques such as contact angle determination, TGA and XRD, were conducted to verify the improvement brought to the UPR by the addition of montmorillonite clay.

\section{Experimental}

\subsection{Materials}

A commercial unsaturated polyester, Polycol 03 - 027PL (pre-added with a cobalt promoter), and an ammonium modified montmorillonite clay were provided by Chemrez, Inc.. Methyl ethyl ketone peroxide (MEKP) (Akzo Nobel) was used as received.

\subsection{Clay loading of the unsaturated polyester resin (UPR)}

Appropriate weights of Polycol 03 - 027PL, a commercial UPR from Chemrez, Inc., were weighed in five separate plastic containers. Then, various amounts of high purity long chainalkyl ammonium modified montmorillonite was incorporated into the four containers to prepare $1 \%, 3 \%, 5 \%$ and $10 \% \mathrm{wt} /$ wt clay with respect to the total mass of the UPR resin and the MEKP initiator). They were then hand mixed until no visible clay aggregates are present. The mixtures were set aside until ready to be cured. The fifth container only contained the resin (UPR only).

\subsection{Curing of the unsaturated polyester resin (UPR) and its composites}

One part of a free radical initiator, methyl ethyl ketone peroxide (MEKP), was added to each of the five containers. The contents were mixed for 1 minute and were subsequently poured into dog bone-shaped silicone molds. These were then allowed to polymerize for 15-20 minutes. Finally, the cured composites were post-cured at $70 \pm 1^{\circ} \mathrm{C}$ in an oven for 3 hours. These were then set aside until ready to be tested.

\subsection{Characterization}

\subsubsection{Tensile Strength Determination}

The tensile strength of the prepared composites and bare UPR samples were measured using a universal testing machine (UTM). First, the width and thickness of the samples previously cured in silicone molds were measured. These data were used to obtain the cross-sectional area. Then, the force required to reach the breaking point was measured using a Multiensayo Electromechanical Universal Testing Machine (UTM). The tensile strength was calculated by dividing the force by the cross-sectional area. Appropriate unit conversions to report the obtained values in megapascals $(\mathrm{MPa})$ was done. Finally, the tensile strength values were plotted against the amounts of clay in percent.

\subsubsection{Contact Angle (CA) Determination}

The contact angle was measured using Attension Contact Angle Machine. This was done by placing a drop of water with volume of $5.0 \pm 0.1 \mu \mathrm{L}$ in a stage and was imaged using a camera attached to a computer with the appropriate software.
The left and right contact angles were measured and three trials were done for each. The average of the last measurement of the right and left ones were reported. This analysis was done to determine if there was an improvement in the hydrophobicity of the nanocomposites.

\subsubsection{Thermogravimetric Analysis (TGA)}

The thermal degradation of the UPR and nanocomposites was monitored using TGA55 (TA instruments). First, the instrument was calibrated for mass and temperature and was set to zero. Then, samples of the prepared composites, as well as the clay, (about 20-30 mg) were weighed in the platinum HT pan. Each of the samples was then subjected to a constant heating rate of $20^{\circ} \mathrm{C} /$ minute from $25^{\circ} \mathrm{C}$ to $1000^{\circ} \mathrm{C}$.

\subsubsection{X-ray Diffraction (XRD) Analysis}

The clay and the composite containing $1 \%$ clay (to represent various prepared samples), were powdered and subjected to X-ray diffraction analysis using Shimadzu XRD 6000. The radiation source is $\mathrm{CuK}_{\alpha}$ with a generator voltage of 40 $\mathrm{kV}$, a generator current of $30 \mathrm{~mA}$, and a wavelength of 1.54 angstroms. The divergence is $1^{\circ}$, same with the scatter, with the receiving at $0.3 \mathrm{~mm}$. Scanning was continous with a step of $0.02^{\circ}$ and a speed of $2^{\circ} /$ minute. The purpose of this analysis is to confirm the successful dispersion of the clay into the resin matrix via exfoliation.

\subsubsection{Scanning Electron Microscopy (SEM)}

Prior to the analysis proper, a small sample from the fractured portion of the UPR as-is, UPR with $3 \%$ and $10 \%$ montmorillonite clay, and montmorillonite clay itself were obtained and dried in an oven at $100 \pm 1{ }^{\circ} \mathrm{C}$ for 1 hour. Then, they were stored in a dessicator until ready to be analyzed to ensure complete dryness. The samples were then mounted in an SEM pin holder and were gold coated for better conductivity. The holder was then placed in the sample chamber of JEOL JSM - 5310 scanning electron microscope. The samples were imaged using an accelerating voltage of $10 \mathrm{kV}$ and different magnifications as per requirement (750-15,000x).

\section{Results and discussion}

\subsection{Preparation of clay-UPR composites}

This work describes the preparation of clay-UPR composites and the subsequent measurement of the tensile strength to see if there is any improvement that occured for the aforementioned property. In this method, the composites were prepared by: (1) incorporation of different amounts of clay $(1 \%, 3 \%, 5 \%$, and $10 \%)$ into the UPR matrix by simple hand mixing until no visible clay aggregates are present; (2) addition of free radical initiator (MEKP) and further hand mixing; (3) pouring of the mixture into the dog bone - shaped silicone mould to polymerize for 15 - 20 minutes; and finally, (4) post - curing at a $70 \pm 1{ }^{\circ} \mathrm{C}$ oven for 3 hours.

The uncured composite samples exhibited a noticeable increase in viscosity compared to the neat resin as mixing these samples is more difficult than the latter. The increase in viscosity 
can be related to the added clay to the UPR. The mixtures though are stable and no noticeable phase separation was observed.

After curing in the dog bone-shaped molds, prepared composites showed no presence of clay aggregates and appeared homogeneous. The visual inspection is an evidence of good dispersion of the clay in the nanocomposite. However, as the amount of clay increases, the more hazy the resin becomes.

\subsection{Tensile strength characterization of clay-UPR composites}

Fig. 1 shows the plot of tensile strength as a function of clay amount in percent. The tensile strength of the neat UPR is at $26.45 \mathrm{MPa}$ and it increased to $39.12 \mathrm{MPa}$ (an increase of $44.04 \%$ ) when $1 \%$ wt/wt clay was added. Furthermore, when the clay loading was increased to $3 \% \mathrm{wt} / \mathrm{wt}$, the tensile strength increased to $47.94 \mathrm{MPa}$ (+57.90\%). However, at 5\% wt/wt clay loading, the tensile strength decreased to $30.34 \mathrm{MPa}$ and at the $10 \% \mathrm{wt} / \mathrm{wt}$ clay level, it was at $31.12 \mathrm{MPa}$. This shows that the tensile strength is improved at a certain level but will begin to decrease at higher loadings. In this particular study, the $3 \%$ wt/wt is the optimum clay loading for the composites that provides the highest increase in the tensile strength. At higher concentrations, the clay particles will start to aggregate once more and will take up more space within the polymer matrix. This will weaken the polymer network and consequently the tensile strength.

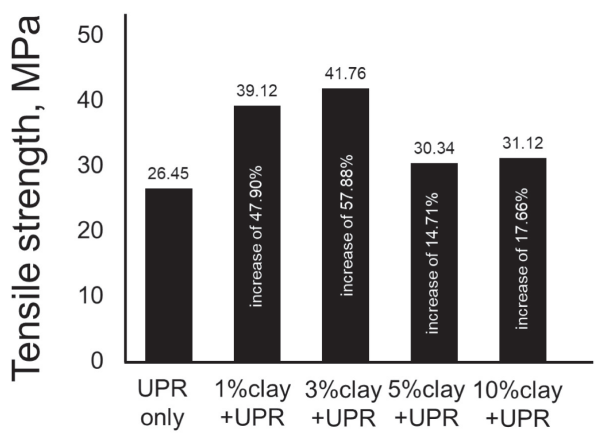

Fig. 1 Tensile strength as a function of clay amount. The composite with the 3\% wt/ $w t$ clay + UPR has the highest tensile strength, with the trend going upwards from the bare UPR ( $0 \% \mathrm{wt} / \mathrm{wt}$ clay) then downwards to the one with $5 \% \mathrm{wt}$ ) $w t$ clay $+U P R$. All composites have higher tensile strengths compared to the bare UPR.

1. ábra Húzószilárdság az agyag mennyiségének függvényében. A 3 tömeg\% agyag + UPR kompozitnak van a legnagyobb a húzószilárdsága, a tendencia a tiszta UPR-töl felfelé halad (0 tömeg\% agyag), majd lefelé az 5 tömeg\% agyag + UPR felé. Valamennyi kompozitnak nagyobb a húzószilárdsága a tiszta UPRhez képest.

\subsection{Wetting behavior of clay-UPR composites as measured in terms of contact angle}

The contact angle curve as a function of the clay loading percentage is shown in Fig. 2 with representative images of each sessile drop. Very much like the tensile strength profile, it has an optimum loading at $5 \% \mathrm{wt} / \mathrm{wt}$ with $84.01^{\circ}$ (equivalent to $14.00 \%$ increase). The contact angle of the base resin is at $73.70^{\circ}$ and it increased to $79.98^{\circ}$ at $1 \% \mathrm{wt} / \mathrm{wt}$ and further increase to $82.75^{\circ}$ at $3 \% \mathrm{wt} / \mathrm{wt}$ clay. However, it decreased to $82.29^{\circ}$ at the $10 \% \mathrm{wt} / \mathrm{wt}$ loading of the clay. The possible explanation for this behavior is that as the amount of clay is increased, the amount of the organic modification attached to the clay is increased.
Therefore, the composite becomes more hydrophobic. However, at a certain level, the clay particles will revert to its organized crystal structure and will form aggregates. Thus, the exposed long chain alkyl modification will decrease and the hydrophobicity will decrease. Consequently, the contact angle will also decrease.

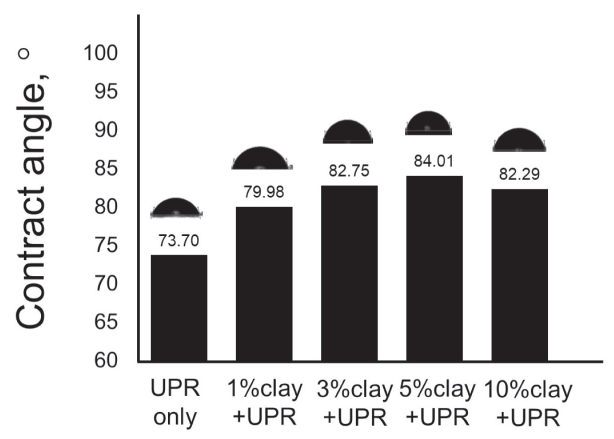

Fig. 2 Contact angle as a function of clay amount. The composite with the 5\% wt/ $w t$ clay $+U P R$ has exhibited the highest contact angle, with the trend going upwards from the bare UPR ( $0 \% \mathrm{wt} / \mathrm{wt}$ clay) then downwards to the one with $10 \% \mathrm{wt} / \mathrm{wt}$ clay + UPR. All composites have higher contact angles compared to the bare UPR. Inset: Representative sessile drops for each sample.

2. ábra Az érintkezési szög az agyag mennyiségének függvényében. Az 5 tömeg\% agyag + UPR kompozitnak van a legnagyobb érintkezési szöge, a tendencia a tiszta UPR-töl növekszik (0 tömeg\% agyag), majd csökken a 10 tömeg\%-os agyag + UPR irányába. Valamennyi kompozitnak magasabb az érintkezési szöge mint a tiszta UPR-nek.

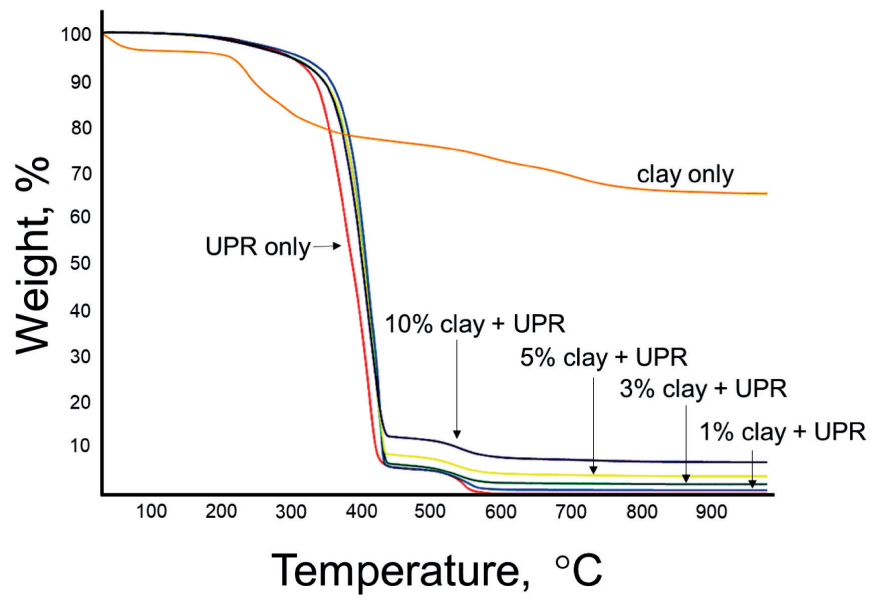

Fig. 3 TGA thermograms of the bare UPR, the clay only and the prepared composites. A clear shift in the thermal degradation profile was observed for all composites and the one with $1 \% \mathrm{wt} / \mathrm{wt}$ clay has the greatest shift (blue curve) from the neat UPR (red curve).

3. ábra A tiszta UPR, a tiszta agyag és az elkészitett kompozitok TGA-termogramjai. A termikus bomlási profilban egyértelmü eltolódást figyeltünk meg az összes kompozit esetében, és az 1 tömeg\% agyagot tartalmazónak van a legnagyobb eltolódása (kék görbe) a tiszta UPR-tól (piros görbe).

\subsection{Thermogravimetric analysis of clay-UPR composites}

The thermogravimetric (TGA) plots of the UPR, clay, and the resulting composites are shown in Fig. 3. There is a very clear shift in the thermal degradation profile when clay is incorporated into the UPR, albeit the UPR and composites have the same trend. Moreover, the thermogram shows that the composites have three major components: the crosslinked UPR (degrades at around 224-424 ${ }^{\circ} \mathrm{C}$ ), additives (degrades at around $424-524{ }^{\circ} \mathrm{C}$ ) and the residue (the clay itself). The clay has a different profile compared to the UPR and the composites. Its first degradation is at a lower range $\left(<100{ }^{\circ} \mathrm{C}\right)$, 
most likely due to moisture. The second one is at around 224$324{ }^{\circ} \mathrm{C}$, which most likely is the long chain alkylammonium modification. The clay residue is $70 \%$ of the total initial mass. The clay-UPR composites, on the other hand, have residues corresponding to the approximate clay loadings for each as can be noticed at the tail end of the thermogram.

\subsection{X-ray diffraction characterization of the clay template and the clay-UPR composite}

The clay and the $1 \% \mathrm{wt} / \mathrm{wt}$ clay-UPR composite were subjected to XRD analysis to confirm if there is exfoliation of the clay particles in the UPR matrix, that could be a reason for the observed increased in mechanical characteristic, wetting behavior and thermal property of the composites over the bare UPR. This is shown in Fig. 4. For the clay, the characteristic peak is shown at $4.16^{\circ}$, which corresponds to a d-spacing of 10.60 angstroms. This is the typical montmorillonite clay interlayer spacing. For the $1 \%$ wt/wt clay-UPR composite sample, the peak at $4.16^{\circ}$ disappeared. This indicates the delamination of the clay layered structure, favoring the successful dispersion of the clay in the UPR matrix. It has been shown in the literature that exfoliation of previously organically-modified fillers in clay-based polymer nanocomposites have led to enhanced physical properties of the resulting composites materials over their bare polymer counterparts $[7-9,16,18]$.

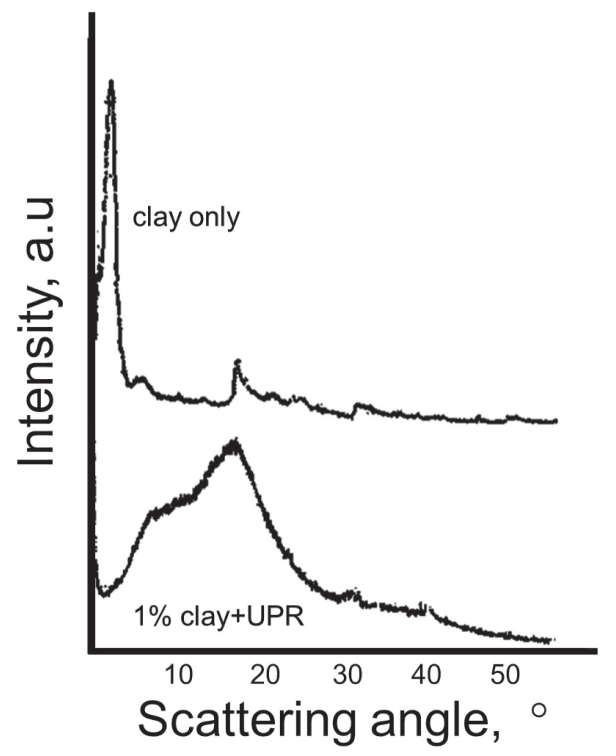

Fig. 4 XRD plots of clay only and $1 \% w t / w t$ clay + UPR. The distinguishing peak at $2 \theta=4.16^{\circ}$ for the clay only has disappeared in $1 \% \mathrm{wt} / \mathrm{wt}$ clay $+U P R$ suggesting exfoliation of the clay in the UPR matrix.

4. ábra XRD ábrán a tiszta agyag valamint az 1 tömeg\%-os agyag + UPR kompozit. A kiemelkedö csúcs $2 \theta=4.16^{\circ}$-nál 1 tömeg\%-os agyag + UPD kompozit esetén nincs jelen, ami az agyag leválására utal az UPR mátrixban.

3.6 Scanning electron microscopy of the bare UPR, the clay template, and the clay-UPR composites

The neat UPR, the clay and two composite samples containing $3 \%$ and $10 \% \mathrm{wt} / \mathrm{wt}$ clay were analyzed under scanning electron microscope (SEM) to confirm the dispersion of the clay in the UPR matrix. As shown in Fig. 5, flake-like and stacked morphology is evident for the montmorillonite clay image (Fig. $5 a$ ). The neat UPR also has a smooth appearance, which is to be expected as it is devoid of any filler material (Fig. 5b). However, upon addition of $3 \% \mathrm{wt} / \mathrm{wt}$ clay, it was very evident that some clay particles aggregated. However, most of them are present as individual primary particles that are smaller in size (Fig. 5c). As the amount was increased to $10 \% \mathrm{wt} / \mathrm{wt}$, the clay flakes began to embed themselves in the UPR matrix (Fig. $5 d$ ). This is due to the sheer number of clay particles that are already present in the sample.

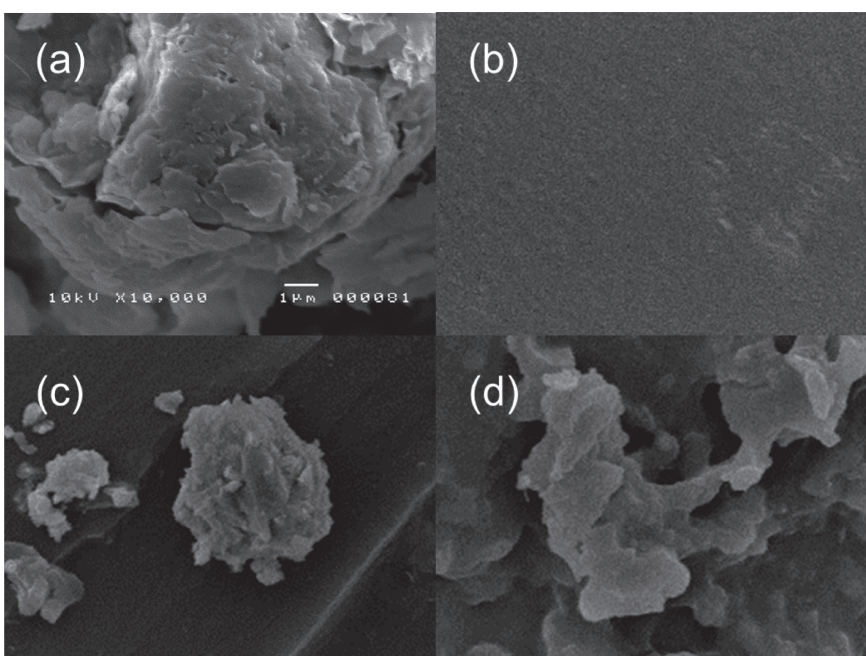

Fig. 5 SEM images of (a) clay only, (b) UPR only, (c) 3\%wt/wt clay + UPR, and (d) $10 \% w t / w t$ clay + UPR. Note the flake - like and stacked morphology of the clay platelets in (a). The "clean" image of the neat UPR is very evident in (b). Few clay agglomerates were present in (c) with the smaller particles outnumbering them. Flakes were seemingly "embedded" in the UPR matrix in (d).

5. ábra SEM képek a) tiszta agyagról, (b) tiszta UPR-röl, (c) 3 tömeg\%-os agyag + UPR kompozitról és (d) 10 tömeg\%-os agyag + UPR kompozitról. Megfigyelhetö az a) pontban emlitett agyaglemezek lemez-szerü és egybe tömörülö formája. A tiszta UPR homogén jellege jól látható a (b) ábrán. A (c) ábrán egy kevés agyag-agglomerátum látható, valmint több különálló kisebb méretü részecske. A (d) ábrán megfigyelhető, hogy az agyag lemezek látszólag „beágyazódtak” az UPR mátrixba.

\section{Conclusions}

We have successfully enhanced the tensile strength, wetting behavior and thermal property of a commercial UPR by incorporation of small amounts of long chain alkylammoniummodified montmorillonite clay. Tensile strength of the composites was measured with the incorporation of $1 \%$ and $3 \% \mathrm{wt} / \mathrm{wt}$ clay resulting in $47.94 \%$ and $57.90 \%$ improvement, respectively, of the resulting composites over the bare UPR sample. However, using 5\% and 10\% wt/wt clay loadings did not result in higher tensile strength but still improved the mechanical property of the prepared composites over the bare UPR. The hydrophobicity was also enhanced as exhibited by increased contact angles of the composites. It improved by as much as $14.00 \%$ at the $5 \% \mathrm{wt} / \mathrm{wt}$ clay loading. The TGA data supports that the addition of clay results in the thermal characteristic enhancement as there is a shift in the degradation profile at higher temperature exhibited by the composites versus the neat UPR with $1 \%$ wt/wt clay-UPR exhibiting the highest degradation temperature. XRD and SEM data confirm the successful exfoliation and dispersion of the added clay fillers in the UPR matrix. 


\section{Acknowledgements}

The De La Salle University through its University Research Coordination Office (URCO) is acknowledged for the funding (URCO 28FU2TA15-3TAY16). Chemrez, Inc. and D\&L Industries, Inc. are also thanked for their technical assistance.

\section{References}

[1] Yang, Y.S. - Lee, L.J. (1988): Microstructure formation in the cure of unsaturated polyester resins. Polymer Vol. 29, Issue 10, pp. 1793-1800, https://doi.org/10.1016/0032-3861(88)90393-X.

[2] Baley, C. - Busnel, F. - Grohens, Y. - Sire, O. (2006): Influence of chemical treatments on surface properties and adhesion of flax fibre-polyester resin. Composites Part A: Applied Science and Manufacturing, Vol. 37, Issue 10, pp. 1626-37, https://doi.org/10.1016/j.compositesa.2005.10.014.

[3] Kargarzadeh, H. - Mariano, M. Huang, J - Lin, N. - Ahmad, I. - Dufresne, A. - Thomas, S. (2017): Recent developments on nanocellulose reinforced polymer nanocomposites: a review. Polymer, Vol. 132, pp. 368-93, https://doi.org/10.1016/j.polymer.2017.09.043.

[4] Kamal, M.R. - Sourour, S. - Ryan, M. (2017): Integrated thermorheological analysis of the cure of thermosets, pp. 187-91.

[5] Singh, B. - Gupta, M. - Verma, A. (1996): Influence of fiber surface treatment on the properties of sisal-polyester composites. Polymer Composites, Vol. 17, Issue 6, pp. 910-18, https://doi.org/10.1002/pc.10684

[6] Atiqah, A. - Maleque, M.A - Jawaid, M. - Iqbal, M. (2014): Development of kenaf-glass reinforced unsaturated polyester hybrid composite for structural applications. Composites Part B: Engineering, Vol. 56, pp. 68 73, https://doi.org/10.1016/j.compositesb.2013.08.019.

[7] Sinha Ray, S. - Okamoto, M. (2003): Polymer/layered silicate nanocomposites: a review from preparation to processing. Progress in Polymer Science(Oxford), Vol. 28, Issue 11, pp. 1539-1641, https://doi.org/10.1016/j.progpolymsci.2003.08.002.

[8] Alexandre, M. - Dubois, P. (2000): Polymer-layered silicate nanocomposites: preparation, properties and uses of a new class of materials." Materials Science and Engineering R: Reports, Vol. 28, Issue 1, pp. 1-63, https://doi.org/10.1016/S0927-796X(00)00012-7.

[9] Giannelis, E. P. (1996): Polymer layered silicate nanocomposites. Advanced Materials, Vol. 8, Issue 1, pp. 29-35,

https://doi.org/10.1002/adma.19960080104.
[10] Penaloza, D.P. (2019): Enhanced mechanical, thermal and barrier properties of clay-based polymer nanocomposite systems. Epitoanyag Journal of Silicate Based and Composite Materials, Vol. 71, Issue 3, pp.7479, https://doi.org/10.14382/epitoanyag-jsbcm.2019.13.

[11] Paul, D. R. - Robeson, L. M. (2008): Polymer nanotechnology: nanocomposites. Polymer, Vol. 49, Issue 15, pp. 3187-3204, https://doi.org/10.1016/j.polymer.2008.04.017.

[12] Penaloza, D. P. (2019): Review on the preparation and properties of clay-based nanocomposites. Philippine Journal of Science, Vol. 148, Issue 4, pp. 827-38.

[13] Penaloza, D.P. - Seery,T.A.P. (2020): Utilizing exfoliated clay-poly (norbornene) nanocomposite prepared by metal-mediated surface-initiated polymerization as model end-tethered polymers on an organoclay substrate. Journal of Applied Physics, Vol. 127, Issue 16, 164702, https://doi.org/10.1063/1.5143825.

[14] Penaloza, D. P. - Sandberg, D. J. - Giotto, M. V. - Seery, T. A. P. (2015): An exfoliated clay-poly(norbornene) nanocomposite prepared by metalmediated surface-initiated polymerization. Polymer Engineering and Science, Vol. 55, Issue 10, pp. 2349-2354, https://doi.org/10.1002/pen.24123.

[15] de Paiva, L.B. - Morales, A.R. - Valenzuela Díaz, F.R. (2008): Organoclays: properties, preparation and applications. Applied Clay Science, Vol. 42, Issue 1-2, pp. 8-24, https://doi.org/10.1016/j.clay.2008.02.006.

[16] Fu, X. - Qutubuddin, S. (2001): Polymer-clay nanocomposites: exfoliation of organophilic montmorillonite nanolayers in polystyrene. Polymer, Vol. 42, Issue 2, pp. 807-13, https://doi.org/10.1016/S0032-3861(00)00385-2.

[17] Penaloza, D. P. - Seery, T. A. P. (2018): Silylated functionalized montmorillonite clay for nanocomposite preparation. Epitoanyag Journal of Silicate Based and Composite Materials, Vol. 70, Issue 5, pp.140-145, https://doi.org/10.14382/epitoanyag-jsbcm.2018.26.

[18] Ogawa, M. - Kuroda, K. (1997): Preparation of inorganic-organic nanocomposites through intercalation of organoammonium ions into layered silicates." Bulletin of the Chemical Society of Japan, Vol. 70, Issue 11, pp. 2593-2618, https://doi.org/10.1246/bcsj.70.2593.

\section{Ref.:}

Abobo, Miguel Ibarra D. - Rodriguez, Loida D. - Salvador, Sonia D. - Siy, Henry C. - Penaloza Jr., David P.: Effect of organoclay reinforcement on the mechanical and thermal properties of unsaturated polyester resin composites

Építőanyag - Journal of Silicate Based and Composite Materials, Vol. 73, No. 2 (2021), 63-67. p.

https://doi.org/10.14382/epitoanyag-jsbcm.2021.10

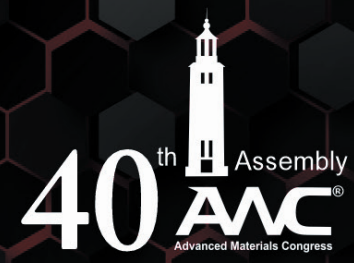

$40^{\text {th }}$ assembly of Advanced Materials Congress (AMC) aims to create an interdisciplinary worldwide forum on Composite Materials Science, Engineering, and Technology. Congress theme,

"Recent Advancements in Composites Materials' Research and Innovations: Breakthrough to Excellence" will facilitate truly interdisciplinary worldwide networking for students, researchers, professionals from academia \& industries and business giants working in the fields of composite materials.

https://www.advancedmaterialscongress.org/cmc/

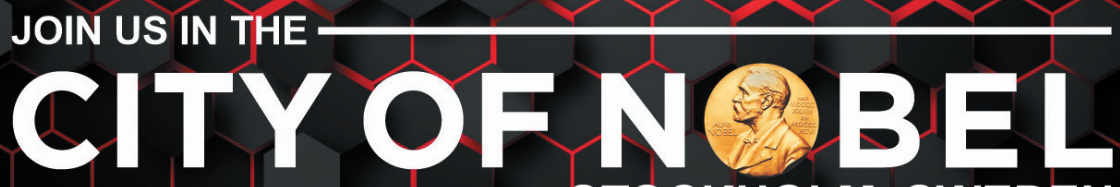

STOCKHOLM, SWEDEN 